\title{
Examination of Critical Thinking Skills of Preservice Science Teachers: A Perspective of Social Constructivist Theory
}

\author{
Umit Demiral $^{1}$ \\ ${ }^{1}$ Faculty of Education, Ahi Evran University, Kirsehir, Turkey \\ Correspondence: Umit Demiral, Faculty of Education, Ahi Evran University, Kirsehir, 40100, Turkey.
}

Received: April 11, 2018

Accepted: May 5, 2018 Online Published: May 15, 2018

doi:10.5539/jel.v7n4p179

URL: https://doi.org/10.5539/jel.v7n4p179

\begin{abstract}
The purpose of this study is to examine the critical thinking skills of preservice science teachers in terms of various variables (gender, grade level, academic grade point average, participation in activities) and their opinions. In the research, sequential explanatory design, which is one of the mixed method research designs, was used. The study was carried out with 200 preservice teachers studying at Science Education Department of a state university chosen at Cappadocia region of Turkey. Interviews were conducted with low-level $(\mathrm{f}=7)$ and high-level $(\mathrm{f}=7)$ preservice teachers selected by means of purposive sampling method from these pre-service teachers participating in the study. Regarding the quantitative and qualitative data obtained; it has been determined that the critical thinking skills of the preservice teachers did not show any significant difference according to gender, grade level and academic grade point average, but there was a significant difference in terms of the activities performed. Preservice teachers expressed that their family structures, social environments in which they interact, and characteristic features were said to be effective in the development of critical thinking skills. Regarding the findings, it has been concluded that trainings that will evoke higher level skills such as critical thinking skills in universities can be effective, but the social and cultural background of the preservice teachers are also effective on these skills. It is recommended to prepare contents that enhance higher level skills such as critical thinking skills as well as education for pedagogy or content knowledge given at universities.
\end{abstract}

Keywords: science education, preservice science teachers, critical thinking skills

\section{Introduction}

Critical thinking (Kuhn, 2005), a form of higher order thinking, is the judging process that directs and regulates problem solving and decision making (Facione, 1990). As a natural consequence of the different approaches of psychologists and educators based on behavioral and cognitive theories on critical thinking, there are various definitions of this concept (Jacobson, McDuff \& Monroe, 2015). Behavioral theorists have defined critical thinking as a skill that involves comparing individual experiences and values with current experiences and new knowledge; decisions and judgments with conditions required (Moore \& Parker, 1998). Cognitive theorists have defined critical thinking as having a logical/thoughtful, attitude/behavior towards the situations and problems encountered by individuals in their own lives, knowledge of the methods of reasoning, accepting the evidence necessary to support what is claimed to be true, having knowledge regarding logical inquiry and reasoning methods (Ennis, 1991; Lipman, 1991; Paul \& Elder, 2008; Dunn, Halonen \& Smith, 2009). APA (1990) has defined critical thinking in the Delphi Report in order to overcome this conceptual difference that takes place for many years in the fields of psychology that are fed from different philosophical trends. According to this, critical thinking is defined as a process of purposeful, self-regulatory judgment that directs problem-solving and decision-making.

The Delphi Project, which plays an important role in overcoming the complexity of defining critical thinking, also clarifies the skills involved in critical thinking. According to the Delphi project, critical thinking skills include cognitive skills such as interpretation, analysis, evaluation, inference, explanation and reflective reasoning. Each of these six skills is at the center and essence of critical thinking (Facione, 1990). The development of these skills is essential because citizens encounter with various decision-making situations due to social difficulties increasingly getting complex and these are the skills that they need to use to overcome this process (Ernst \& Monroe, 2004). 
Several suggestions have been put forward in the literature for the development of critical thinking skills. One of these suggestions is the use of teaching methods in which the student is at the center instead of traditional teaching methods (Belluigi \& Cundill, 2017; Ernst \& Monroe, 2004). Belluigi and Cundill (2017) noted the importance of participating in the process factor to develop critical thinking skills, and reached the conclusion that in the course of a science education in which teachers conducted activities based on environmental education, students actively participated in the process and their critical thinking skills developed with the scientific argumentation in this process. Ernst and Monroe (2004) found out that there is a relationship between critical thinking skills and gender, ethnicity, grade point average, and education based on environmental education in another study that examines critical thinking skills within the scope of an environmental education program. They determined that students developed their critical thinking skills by benefiting from using and synthesizing knowledge, questioning, problem solving and decision making skills against complex environmental problems. In the study they conducted with university students, Terenzi, Springer, Pascarella and Nora (1995) found out that analytical reasoning develops by integrating more than one extracurricular activities (such as science, music, literature and painting) rather than a single curriculum and that as a result of this, students' critical thinking skills develop. For many years, many tests, observation techniques and individual interviews have been used to measure critical thinking skills. Critical thinking skills are measured to determine the students' level of critical thinking ability, to give feedback to students on critical thinking, to motivate students to be critical thinkers, to inform teachers about their successes of teaching critical thinking, to make research on critical thinking and to inform schools about developing critical thinking skills of students etc. (Demir, 2006). Tests developed for different purposes have been used to measure critical thinking skills. However, as one of the most effective ways, necessity of using these techniques together to examine critical thinking skills has been emphasized.

Especially when its place in the developed countries' national science programs is examined, it is seen that one of the main objectives of science education is to raise individuals capable of questioning with a critical perspective (NCCA, 2015; NRC, 1996; AAS, 1989). When Science Teaching Curriculums applied in Turkey are examined, in 2018, with the integration of technology into the national science teaching curriculum, while defining the characteristics of the individual who can catch up with the rapid change in knowledge and technology, it is defined as follows "... an individual who is able to produce knowledge, use it as functional in life, solve problem, think critical, be entrepreneurial and decisive, have communicative skills, empathize with people and contribute to the society and the culture etc." (MNE, 2018). The importance of critical thinking skills in the field of science and technology has been emphasized by expressing that it includes "Safe and critical use of information and communication technologies for business, everyday life and communication" (MNE, 2018), while identifying the individual with digital competence among "Competencies" when examining the content of the science curriculum.

If examine the current situation from the perspective of teacher training system, it is emphasized that teachers need to have experience for the competencies in the curriculum so that they can apply the curriculum effectively (Loughran, 2014). For this purpose, it is seen that many countries have some aims, such as improving the critical thinking skills of preservice science teachers (PSTs) within the standards of teacher training programs. By expressing that "teachers evaluate the knowledge and the skills they acquire with a critical approach" in Learning Competencies within the scope of Turkey Higher Education Qualifications Framework of Higher Education Council (HEC), it is pointed out that PSTs are required to graduate from a teaching program with critical thinking skills (URL-1). According to Ennis (1991), teachers are one of the important factors in the critical thinking skills training. Wilks (1995) pointed out that teachers should have critical thinking skills and good pedagogical knowledge in order to raise students who question, participate more, discuss more, determine their predictions and priorities and ask questions for alternatives. Teachers use a variety of instructional strategies to improve their students' critical thinking skills, problem solving skills and performances (Ten Dam \& Volman, 2004) and they need to know for what purpose they use instructional strategies. For this reason, the training of teachers has a very special place in thinking skills training.

Despite the emphasized importance of critical thinking skills for PSTs, in the studies conducted, it has been found out that the critical thinking skills of PSTs are not sufficient enough (Ashton, 1988; Lin, 2014). In one of the studies conducted on this subject, Ashton (1988) stated that the main obstacle for the school while raising individuals who think critically is that teachers do not have critical thinking tendencies and skills. In another study, Lin (2014) found out that the critical thinking skills of university students lacking content knowledge were at low level. 
If a general evaluation is made about the literature examined for critical thinking skills, it is seen that the critical thinking skills of the PSTs who will be teachers in the following years, are low; and inadequacies in the content knowledge (Demiral, 2014; Demiral \& Çepni, 2018) and the training of PSTs with expository teaching approach (Belluigi \& Cundill, 2017; Ernst \& Monroe, 2004) seem to be effective on this. Finally, when the national studies conducted in Turkey sample are examined, it is seen that many studies have been carried out superficially. For example, a number of methodological limitations have been identified in studies. In these studies, it is seen that the screening method, which is one of the descriptive researches, was used. There are limitations in determining the critical thinking skills with just one measuring tool. Moreover, it is seen that there are some problems in the age group addressed by the measuring instruments used in the studies. That is to say, it is seen that measuring instruments developed for the age group 17 and above or; secondary school or high school students were applied to PSTs. In short, it can be said that there are some gaps regarding critical thinking in terms of methodology, measurement tools and theoretical background. In the present study, quantitative and qualitative measuring instruments prepared for the age group of the PSTs were preferred. In addition, prior to the main application of these measurement tools, the validity and reliability of them were tested via pilot study and item analysis was carried out. Another important aspect of the study is that findings obtained were examined within the context of social-constructivist theory and tried to be interpreted deeply.

The purpose of this study is to examine the critical thinking skills of PSTs and their thoughts related to these skills. Within this context, the following questions were searched:

1) Does the level of PSTs' critical thinking skills differ in terms of their demographic characteristics (gender, grade level, academic grade point average, participation in activities, reading levels)?

2) What are the thoughts of PSTs on the critical thinking skills they have?

\section{Method}

\subsection{Research Desing}

In this study, one of the mixed method research designs, the sequential explanatory design, was used. Sequential explanatory design is a mixed method research design that the researcher begins by managing a quantitative research and collects qualitative data as a second step and then search for specific results (Creswell, 2003; Creswell \& Plano-Clark, 2011). The reason why this design was chosen for the study is to explain the relationship between the critical thinking skills of the PSTs and some variables.

The present study was carried out in two stages. First, the relationship between critical thinking skills and factors such as gender, grade level, participation in activities, is presented for the quantitative dimension. Then, as the second dimension, in the qualitative part, the relations revealed by the quantitative data obtained from the face-to-face interviews with the PSTs are explained.

\subsection{The Study Group}

This study was conducted at a state university in the Cappadocia region of Turkey. For the research, participants in each grade were asked to participate in the study voluntarily, so all of the PSTs in the class did not participate in the study and only volunteer PSTs participated. The gender distribution of 200 PSTs participating in the study according to the grade level is shown in Table 1 below. The face-to-face interviews with 14 PSTs selected from these 200 PSTs were conducted.

Table 1 . Distribution by gender and class level

\begin{tabular}{|c|c|c|c|c|c|c|c|}
\hline & & & \multicolumn{4}{|c|}{ Grade } & \multirow[b]{2}{*}{ Total } \\
\hline & & & $1^{\text {st }}$ grade & $2^{\text {nd }}$ grade & $3^{\text {rd }}$ grade & $4^{\text {th }}$ grade & \\
\hline \multirow[t]{4}{*}{ Gender } & Male & $\mathrm{N}$ & 21 & 13 & 19 & 21 & 74 \\
\hline & & $\%$ & $\% 28.4$ & $\% 17.6$ & $\% 25.7$ & $\% 28.4$ & $\% 100$ \\
\hline & Female & $\mathrm{N}$ & 34 & 35 & 26 & 31 & 126 \\
\hline & & $\%$ & $\% 27$ & $\% 27.8$ & $\% 20.6$ & $\% 24.6$ & $\% 100$ \\
\hline \multirow{2}{*}{\multicolumn{2}{|c|}{ Total }} & $\mathrm{N}$ & 55 & 48 & 45 & 52 & 200 \\
\hline & & $\%$ & $\% 27.5$ & $\% 24$ & $\% 22.5$ & $\% 26$ & $\% 100$ \\
\hline
\end{tabular}




\subsection{Data Collection Tools}

\subsubsection{Personal Information Scale (PIS)}

In order to increase the accuracy of the comments, it is important to know the personal information of the participants for the research of the abstract issues if the researcher is going to solve the research problem through the quantitative approach (Morse, 2003). Some demographic information such as gender, grade level, activities that PST participated, grade point average, was tried to be collected in this part. Possible factors affecting critical thinking skills were tried to be revealed via these variables, which were collected. In this context, by using the personal information scale, certain information was gathered about the participants and the social circles they grew up in.

\subsubsection{Watson Glaser Critical Thinking Appraisal (WGCTA)}

WGCTA was used to measure the levels of PSTs' critical thinking skills. The measurement tool is initially developed to be applied to a group from the $9^{\text {th }}$ grade students to the first year students in the university but it is also used in managerial development programs to develop critical thinking skills in the industry as well as in the selection and placement of personnel along with other measurement tools and in various special education programs (Watson \& Glaser, 1980). With this feature, it can be said that it is suitable for the age group of PSTs who are studying at university.

Watson and Glaser consider critical thinking skills as identifying a problem, recognizing appropriate choices or strong assumptions for resolving the problem, making correct deductions for solution and evaluating them (Çıkrıkçı, 1993).

The scale consists of 100 items in its original form. It was adapted to Turkish by Çıkrıçı (1993). Legal and ethical permission has been obtained by the researcher for the application of the measurement tool in the present study. Then a pilot study was first conducted to demonstrate the appropriateness of the instrument to the sample group. As a result of the pilot study, item analysis was carried out and the KR-20 value of the test was found to be .73. Inference dimension of the scale consists of 16 items, recognition of assumptions dimension 14 items, deduction dimension 16 items, interpretation dimension 21 items, and evaluation of arguments dimension 10 items.

\subsubsection{Interview Questions}

To explain the causes of quantitative data and to collect more detailed data, face-to-face interviews were conducted with 14 pre-service teachers having critical thinking skills at different levels ( $f=7$ low level; $f=7$ high level). During this interview, at first it was asked to the PSTs what critical thinking was, but this question was not answered. Therefore, brief information was given about critical thinking to each PST interviewed, and then the following interview questions were asked.

Interview Question -1: What do you think about the level of your critical thinking skills?

Interview Question-2: In your opinion, what could be the reasons for your critical thinking skills being low/high?

\subsection{Data Analysis}

\subsubsection{Quantitative Dimension}

SPSS 20 package program was used during the analysis of the data obtained in the study. Before proceeding to the analysis process, within the context of normality tests, the kurtosis-skewness and Kolmogorov-Smirnov normality tests were performed to determine whether the distributions at each dependent variable level were normal or not. According to the results of the analysis made, it was determined that the distribution for the critical thinking test data was normal in all groups (kurtosis-skewness between -1.96 and +1.96 ; $>$. 05 for Kolmogorov-Smirnov normality test). It was decided to use parametric tests for this. During the analysis of the data obtained from the tests; frequency (f), percentage (\%), mean $(\bar{x})$ and standard deviation (SD) values were used as descriptive statistics; one-way ANOVA test was used as an exploratory statistics technique for unrelated samples. In the determination of the groups (low-middle-high) to be compared, $\overline{\mathrm{x}}-1 \mathrm{SD}<\overline{\mathrm{X}}<\overline{\mathrm{X}}+1 \mathrm{SD}$ formula was used.

\subsubsection{Qualitative Dimension}

The data obtained from the interviews conducted with the PSTs in the study were analyzed by inductive content analysis method. For audio and video recordings, permission was asked from PSTs participating in the focus group interview, which is one of the data collection techniques in qualitative researches. After taking the required ethical permissions, interviews carried out with PSTs were recorded with audio recorder and camera. In 
addition to these, during the interview, the researcher frequently took notes about the interview. Received audio, video and written records were transcribed with Microsoft Office Word program. In the inductive content analysis method carried out for the data analysis, the data were analyzed by extracting data in the first step, then determining codes, and creating themes from the codes at last stage (Miles \& Huberman, 1994).

\section{Results}

Results related to the critical thinking skills of PSTs are presented under following subtitles; a) quantitative and b) qualitative findings. Results related to the first research question are presented in the quantitative findings part of the study, and Results related to the second sub-problem of the study in the qualitative findings part.

\subsection{Quantitative Findings}

\subsubsection{Gender Variable}

Findings related to the subscales of the PSTs' critical thinking skills according to gender are given in Table 2.

Table 2. T-test results of critical thinking scale scores by gender

\begin{tabular}{|c|c|c|c|c|c|c|c|}
\hline $\begin{array}{l}\text { Sub-dimensions of critical } \\
\text { thinking skills }\end{array}$ & Gender & $\mathbf{N}$ & $\overline{\mathbf{x}}$ & SD & df & $\mathbf{t}$ & $\mathbf{P}$ \\
\hline Make correct inferences & Male & 74 & 7.31 & 2.13 & 198 & .04 & .965 \\
\hline \multirow[t]{2}{*}{ To recognise assumptions } & Male & 74 & 8.71 & 2.07 & 198 & .50 & .613 \\
\hline & Female & 126 & 8.86 & 1.96 & & & \\
\hline \multirow[t]{2}{*}{ To come to conclusions } & Male & 74 & 13.68 & 2.93 & 198 & 1.27 & .205 \\
\hline & Female & 126 & 14.23 & 2.88 & & & \\
\hline \multirow{2}{*}{$\begin{array}{l}\text { To interpret and evaluate } \\
\text { arguments }\end{array}$} & Male & 74 & 4.87 & 1.58 & 198 & .114 & .909 \\
\hline & Female & 126 & 4.84 & 1.83 & & & \\
\hline
\end{tabular}

According to the data in Table 2, the critical thinking skills of PSTs do not show a significant difference according to gender $\left[\mathrm{t}_{(198)}=.98, \mathrm{p}>.05\right]$. The critical thinking skills of male PSTs $(\overline{\mathrm{X}}=43.63)$ and the critical thinking skills of female PSTs $(\overline{\mathrm{X}}=44.68)$ are close to each other. When the gender variable is examined in the sub-dimensions of WGCTA, inference $\left[\mathrm{t}_{(198)}=.04, \mathrm{p}>.05\right]$, recognition of assumptions $\left[\mathrm{t}_{(198)}=.50, \mathrm{p}>.05\right]$, deduction $\left[\mathrm{t}_{(198)}=1.13, \mathrm{p}>.05\right]$, interpretation $\left[\mathrm{t}_{(198)}=1.27, \mathrm{p}>.05\right]$ and evaluation of arguments $\left[\mathrm{t}_{(198)}=.114, \mathrm{p}>.05\right]$ subscales do not show a significant difference according to gender. This finding can be expressed as there is no significant relationship between critical thinking skills and gender.

\subsubsection{Grade Level Variable}

Findings related to critical thinking skills of PSTs according to grade level are given in Table 3.

Table 3. ANOVA test results according to grade level of critical thinking scale scores

\begin{tabular}{lllllll}
\hline Source of Variance & $\begin{array}{l}\text { Sum of Square } \\
\text { (SS) }\end{array}$ & $\mathbf{d f}$ & $\begin{array}{l}\text { Mean } \\
\text { Square }\end{array}$ & F & P & $\begin{array}{l}\text { Significant } \\
\text { difference }\end{array}$ \\
\hline Between Groups & 313.280 & 3 & 104.427 & 1.996 & .116 & None \\
Within Groups & 10254.315 & 196 & 52.318 & & & \\
Total & 10567.595 & 199 & & & & \\
\hline
\end{tabular}

According to the data in Table 3, the critical thinking skills of the PSTs do not show a significant difference according to the grade level $\left[\mathrm{F}_{(3-196)}=1.996, \mathrm{p}>.05\right]$. In other words, the critical thinking skills of PSTs do not change depending on the grade level. According to the results of the Scheffe test performed to show that there is no statistical difference between grade levels, even if the averages of the first year $(\overline{\mathrm{X}}=43.03)$, second year $(\overline{\mathrm{X}}=43.20)$, third year $(\overline{\mathrm{X}}=45.08)$ and fourth year $(\overline{\mathrm{X}}=45.94)$ PSTs are different than each other, this difference is not statistically significant. 


\subsubsection{Academic Grade Point Average Variable}

Findings related to critical thinking skills of PSTs according to their undergraduate academic grade point average are given below. In order to reveal the relationship between the academic achievements of the PSTs and their critical thinking skills, firstly the academic grades of the PSTs are divided into three groups as low, middle and high. The test results are given in Table 4 below.

Table 4. Statistical values of PSTs' academic grade averages

\begin{tabular}{ccccccc}
\hline $\mathbf{N}$ & Mean & SD & Variance & Range & Min. & Max. \\
\hline $\mathbf{2 0 0}$ & 2.493 & .487 & .238 & 2.66 & .88 & 3.54 \\
\hline
\end{tabular}

Using the statistical values given in Table 4, the following formula was used to divide PSTs' academic grade point averages into three groups as low, medium, and high level.

$$
\overline{\mathrm{X}}-1 \mathrm{SS}<\overline{\mathrm{X}}<\overline{\mathrm{X}}+1 \mathrm{SS}
$$

According to this, PSTs were divided as 0.88-2.04 (low) $<2.05-2.93$ (middle) $<2.94-3.54$ (high). The ANOVA results of the critical thinking skills test scores of the PSTs according to their undergraduate academic point averages are given in Table 5 .

Table 5. ANOVA test results of PSTs' critical thinking scale scores according to their academic grade average

\begin{tabular}{lllllll}
\hline Source of Variance & $\begin{array}{l}\text { Sum of Square } \\
\text { (SS) }\end{array}$ & df & Mean Square & F & P & Significant difference \\
\hline Between Groups & 144.776 & 2 & 72.388 & 1.353 & .261 & None \\
Within Groups & 10113.594 & 189 & 53.511 & & & \\
Total & 10258.370 & 191 & & & & \\
\hline
\end{tabular}

According to the data in Table 5, the critical thinking skills of the PSTs do not show any significant difference according to their academic grade point averages $\left[\mathrm{F}_{(2-189)}=.261, \mathrm{p}>.05\right]$. In other words, the critical thinking skills of PSTs do not change depending on their academic grade point averages. According to the results of the Scheffe test performed to show that there is no difference between the academic grade point averages, since the critical thinking skills test scores of the PSTs with low grade point average $(\bar{X}=42.593)$, intermediate grade point average $(\overline{\mathrm{X}}=44.375)$, and high grade point average $(\overline{\mathrm{X}}=45.562)$ are close to each other, there is no statistically significant difference between them.

\subsubsection{Participating in Activities Variable}

The findings regarding PSTs' critical thinking skills according to the activities they participated in are given below. PSTs were asked to choose an activity ((1) scientific, (2) cultural and (3) sportive activities) that they most participate in. According to the activities they participate in, the ANOVA results of PSTs' critical thinking scores are given in Table 6.

Table 6. ANOVA test results according to the activities attended

\begin{tabular}{ccccccc}
\hline Source of Variance & $\begin{array}{c}\text { Sum of Square } \\
\text { (SS) }\end{array}$ & df & Mean Square & F & P & $\begin{array}{c}\text { Significant } \\
\text { difference }\end{array}$ \\
\hline Between Groups & 535.606 & 2 & 253.827 & 4.993 & .008 & $1-3,2-3$ \\
Within Groups & 7670.504 & 143 & 53.640 & & & \\
Total & 8206.110 & 145 & & & & \\
\hline
\end{tabular}

According to the data in Table 6, the critical thinking skills of the PSTs show a significant difference according to the activities they participate in $\left[\mathrm{F}_{(2-143)}=4.993, \mathrm{p}<.05\right]$. In other words, the critical thinking skills of PSTs vary significantly depending on the types of activities they participate in. According to Scheffe test results performed to determine that there is a significant difference between which activities, the critical thinking skills of PSTs participating in (1) scientific activities $(\overline{\mathrm{X}}=46.61)$ and (2) cultural activities $(\overline{\mathrm{X}}=44.97)$ are higher than those who participated in sportive activities $(\overline{\mathrm{X}}=41.30)$. 


\subsection{Qualitative Findings}

Interviews with PSTs with high-level $(\mathrm{f}=7)$ and low-level $(\mathrm{f}=7)$ of critical thinking skills were conducted in order to examine the quantitative findings in depth. The findings obtained as a result of these interviews are given below.

\subsubsection{Low Level Group}

When the interviews conducted with the PSTs in the low-level group were examined, PSTs expressed that they had lower level critical thinking skills due to the themes such as "characteristics features", "social environment", "family", "culture", and "content knowledge".

PSTs in this group coded as PST-1 and PST-2 explained that they have low level of critical thinking skills due to their characteristic features (lack of self-expression, lack of self-confidence, lack of different viewpoints, being unable to comment). PST-1, who associates having low level critical thinking skills to the problem of lack of communication, stated that he cannot communicate because he has difficulties in expressing himself. In his statement, he expressed that "I think that my critical thinking is low because I cannot express myself very well in the front of people, I cannot speak. I cannot open myself truly to the people I have just met because I do not know the reaction of the other side, but I can be more relaxed when I talk to friends I know, I can criticize them...". PST-2, who links having low level critical thinking skills to the lack of self-confidence, stated that "My critical thinking is really low. Whenever someone is superior to me, I have low self-confidence. I cannot interpret the events. I cannot analyze them in detail".

In the interviews conducted with the pre-service teachers, two PSTs (PST-3, PST-11) think that low level of critical thinking skills results from the social environment (family structure). For example, in the interview conducted with PST-3, she stated that "My parents are very dominant in my family. I cannot say my ideas against them. Perhaps, that's why, I cannot speak comfortably in society". Two PSTs (PST-11, PST-13) in the interviews think that the social and cultural environment they were raised in was influential on their critical thinking. In the interview conducted with PST-13, she stated that "I am not inclined to criticize the thoughts of the person talking to me because it is his own opinion, I respect him. I do think it would be up to me to criticize him. I just say my own ideas. I defend my own views. I do not criticize people not to be perceived as if I am contempting or offending them. I think it's a cultural thing...".

In the interviews conducted with the PSTs, one PST (PST-14) thinks that content knowledge influences the critical thinking skills. For example, in the interview with PST-14, she stated that "I only comment on what I know. If the subject is attracting me, I say my opinion in society. If I do not have any knowledge about the subject, I do not talk".

\subsubsection{High Level Group}

When the interviews conducted with the PSTs in the high level group were examined, the PSTs expressed that their critical thinking skills were high due to the themes such as "social environment", "family structure", "characteristics features", "reading" and "university education".

Some PSTs in this group (PST-6, PST-7, and PST-17) think that the social circle they are in is influencing their critical thinking skills. For example, in the interview with PST-6, this PST stated that the sense of worthiness and appreciation that the people show to her is effective. In his statement, PST-6 expressed that "I see among friends at home or outside that my ideas are valued. Maybe my ideas are stronger compared to them or I express them better. It also results from the family. My parents are separated and I have grown up with my grandparents. They are uneducated. They have graduated from the elementary school. I am studying successfully and that allows them to value my ideas. I have even improved myself in university and I have become a more influential person in their eyes...". PST-7 stated that it is effective to observe people and their behaviors. In his statement, she expressed that "In general, people resemble each other; I mean there are a lot of people who are alike. Maybe with their form of speech, or the opinion that they defend, they are effective on my improvement... My parents have also an effect on it. I mean, my parents used to be a bit authoritarian. In time they began to become more democratic. When we talk at these days, they value my views. They want an opinion from me. But when I look at the past, when I looked at my high school life, there was nothing like that, I mean my family was authoritative, what my father says was true". In the interview conducted with PST-17, she stated that his critical thinking skills are high and that this situation is due to being appreciated by her social environment and her family structure. In her statement, PST-17 expressed this as follows "I always think of different alternatives. My friends consult me when they are indecisive. I say my opinion, I try to tell them what is best. There are alternatives in my mind. I tell the strongest one among them according to me. If I have knowledge in one subject, 
I can make a strong comment. My critical thinking is high. I think that my family is very influential on this. They give me the right to speak. I grow up in a democratic environment. For example, when they ask me about my opinion, when it is asked why you think these events are happening, I say my own ideas and discuss them with my family if we are in opposition...". PST-19, another PST who draws attention to the influence of the family on the critical thinking skills, pointed out that the democratic structure of the family is effective on the critical thinking skills, and also stated that decision-making processes in families are also effective on the development of critical thinking skills. PST-19 expressed in her statement that "Everyone in our family tells his/her opinion and the subject are discussed. When a decision is made, even while we are going somewhere, we vote. The objection is expressed comfortably. We try to persuade each other with our reasons while expressing this...". PST coded as PST-9 thinks that her critical thinking skills are high because she has a sense of social responsibility. She expressed this as follows: "I do not think I'm very stubborn or critical, so I am not like that at home, either. If there is a very important issue, for example something that is related to science which is a threat to our health, at such times I have to convince or inform someone about that. Normally I am not a person who criticizes things, but my critical power comes in sight especially for health issues...". PST-9 also thinks that the positive communication of her family with her is also effective. She stated that "My family is authoritarian and protective against me, but when they are going to do something about an issue, they also ask me; should we do this like that? And this makes me happy. I have one younger brother and they usually ask me, not him, and I like it...". PST-18 believes that his family influences his critical thinking skills. In one of his statements about his family, he said that "My family always seemed democratic, but their ideas were always important. This caused me to create a reaction against them. I was judged too many times unjustly. This situation led me to decide after thinking too much in detail and not to harm the other side unnecessarily".

In the interviews conducted with the PSTs, one PST (PST-7) thinks that their intimate observation and curiosity towards the environment affect their critical thinking skills. For example, in the interview with PST-7, he stated that "I think making much observation causes high critical thinking. For example, I sit outside, drink tea, and look at people. What are these people doing? What kind of mood do they have? What kind of speaking style do they have?". PST-19 emphasized listening to different opinions and understanding them. She stated that "I am trying to understand the views of people from every walk of life". PST coded as PST-18 think that questioning has an influence on critical thinking skills. In his statement, PST-18 expressed that "It results from questioning so much in my mind. I do not believe immediately that something is true. I'm trying to do things after thinking well. I think my questioning is becoming a pyramid gradually when I think what I have lived in the past".

\section{Conclusion and Discussion}

\subsection{Gender and Critical Thinking}

According to research findings, it has been determined that there is no significant difference between gender and critical thinking skills. This may be due to the fact that cognitive characteristics of female and male individuals are close to each other. In the study conducted on gender and cognition by Clinton et al. (2014), they have suggested that there is no finding that there is a difference between genders regarding cognitive characteristics, but there is a difference between them regarding episodic memory, verbal and visual-spatial cognition. However, these differences are largely the differences between language and spatial cognition rather than the meta skills that constitute the sub-dimensions of critical thinking. It can be concluded that there is no difference between the genders because no evidence is provided that inference, recognition of assumptions, deduction, interpretation and evaluation of arguments skills which are the subscales of critical thinking skills are directly related to language and episodic memory. In a study supporting this result (Shukla \& Dungsungnoen, 2016), researchers have examined whether high order thinking skills have significantly changed between genders or not. When examined, it has been found out that some high order thinking skills related to critical thinking skills such as analyzing different perspectives, drawing conclusions, questioning and supporting do not make a significant difference between the genders.

\subsection{Teacher Training Program and Critical Thinking}

In the research findings, it has been determined that there is no significant difference between PSTs' critical thinking skills in terms of grade level and academic grade point average because PSTs do not have enough experience to develop their critical thinking skills during monological process based on expository teaching. This may be due to the fact that the education received at the university does not have enough quality to develop critical thinking skills of the PSTs because they do not have enough experience to develop their critical thinking skills during monological process in education that is usually based on expository teaching (Kilinc, Demiral \& Kartal, 2017). The importance of methods that provide opportunity for dialogic communication in the 
development of critical thinking skills have determined that argumentation (Demiral, 2014; Demiral \& Çepni, 2018), inquiry-based activities (Belluigi \& Cundill, 2017; Ernst \& Monroe, 2004) that they have conducted within the context of environmental education develop critical thinking skills. In another study supporting the research findings, Ten Dam and Volman (2004) pointed out the relationship between epistemological belief system and critical thinking. According to them, active learning, problem-based activities, interpersonal interaction promoting practices, learning situations involving real-life conditions are contributing to individuals' epistemological belief systems and that develop the critical thinking skills. In interviews conducted with PSTS, no PST has mentioned the impact of the education they have received at university on their critical thinking skills. This may be a sign that PSTs are being trained through conventional education. As a result, PSTs who try to acquire their teacher identity in a teacher-centered teacher training system are away from the lessons and practices that develop their critical thinking skills and this may be the reason for inhibiting to develop their critical thinking skills at each learning level. Besides, the critical thinking skills of the PSTs who participated in the scientific and cultural activities at university are significantly higher than the PSTs not participating. The activities made within the scope of science activities, science exhibitions of students, conferences, and out-of-school trips conducted at universities may lead the PSTs to interact with each other and gain new experiences related to their field of study and develop their skills such as questioning and problem solving. In the study Terenzi, Springer, Pascarella, and Nora (1995) conducted on university students' critical thinking skills, they found out that out-of-class experiences (such as science, music, literature, and painting) were influential in the development of analytical reasoning and that students' critical thinking skills developed as a result of the experiences they gained in this process. Emphasizing the relationship between the content knowledge and critical thinking skills, PST-14 stated that she is able to make more effective criticisms on issues that he knows. This may indicate that content knowledge is related to criticism, evaluation, and critical thinking performance. In the study Lin (2014) conducted, he found out that university students studying in the science field use the evidences more effective that support the arguments they raise and confute the counter arguments related to the scientific news they read because of the higher level content knowledge they have; thus they use their critical thinking skills more effectively in this process (Demiral, 2014).

\subsection{Characteristic Features-Social Environment and Critical Thinking}

In interviews carried out with PSTs, PSTs have particularly emphasized the character they have and the social environment that is influential in shaping this character for having higher or lower order critical thinking skills. In the formation of the character, the influence of the family and the social environment is obvious in addition to the innate characteristics of the PST. Some of the PSTs have difficulty in approaching the opposing discourse with a critical point of view through mutual communication and that could be happening because they feel themselves in an unsafe environment. When examining the family structures of these PSTs, it is seen that they are generally repressive and overprotective families. Important decisions for their lives are taken by their families for PSTs who grow up in this kind of family structure. They cannot express their own decisions and opinions due to this pressure. In the study conducted by Halpern (1998) who describes the characteristics of critically-minded individuals, while talking about the characteristics of the individuals who have critical thinking skills, he expressed that critically-minded individuals are the individuals who can analyze their arguments, test hypotheses, think in terms of probability and uncertainty, make a decision, solve problems and also have verbal reasoning skills. As can be seen here, the critical thinking skills of the individuals who do not have sufficient verbal communication skills are also low. PSTs who grow up in overprotective and authoritarian families are avoiding facing with a problem because of the pressure they are exposed, or are not making an effort to solve that problem. As a result of this, when they are faced with some issues, they are far from gaining experience skill. The lack of experience they face in their daily lives may be suppressing their thinking skills. On the other hand, the individual who grows up in the democratic and caring family structure may develop his/her critical thinking skills with self-confidence and new experiences thanks to trust and problem-solving opportunities presented to $\mathrm{him} / \mathrm{her}$. Another effect of the social circle is it creates a model for the individual. The fact that PST coded as PST-7 expressed that the behavior of the people around him is effective on improving his critical thinking skills may be due to the fact that people whom he communicates with are a model for him. PST-9 expressed that appraisal of her views was effective on her critical thinking skills even though her family was authoritarian and protective. This can be the result of the fact that her family created environments that allowed her to gain new experiences. PST-18 has developed some forms of thought as an internal reaction to justify his own ideas against repressive attitude of his family. In his study, Halpern (1998) emphasizes the reflective, self-assessing nature of critical thinking and draws attention to the importance meta-cognitive skills required for it. In addition to this, Paul (1992) stated that critical thinking is artificial in situations where individuals are not taught certain criteria to evaluate their own thinking. For Kuhn (1999), epistemological beliefs questioning the validity of 
meta-cognitive skills and knowledge are crucial for critical thinking. Therefore, the higher order critical thinking feature of PST-18 which emerged as a result of the higher level epistemological beliefs of him might have led to questioning of family members' ideas and self-evaluation feature.

Moreover, some PSTs expressed that they had the sense of observation and curiosity for the events taking place around them. Features of innate curiosity and questioning for events around them can be an effective factor in the development of their critical thinking skills. A PST (PST-14) stated that she could make a number of criticisms on subjects that she knows. Here, it reveals the influence of the content knowledge in science education on critical thinking because the perception of self-efficacy of the people with high content knowledge is high. PSTs with high self-efficacy have high self-confidence and that may be contributing to them at the point of criticizing the views that they are interacting (Demiral, 2014; Demiral \& Çepni, 2018).

\section{Suggestions}

\subsection{Suggestions for Teacher Training Program}

PST coded as PST-19, who scored high on the critical thinking test, expressed that every individual expresses her opinion and they try to persuade each other while deciding on a subject with her family. Considering in terms of education, it is obvious that PSTs' having more experiences for the practice of argumentation during the undergraduate period will be effective in the development of their skills such as questioning, decision making and persuading each other. Therefore, it is recommended that activities such as argumentation should be frequently included as well as content knowledge during the undergraduate period.

It is pointed out in the related literature that the use of contemporary events in lessons contributes to the development of critical thinking skills (Doğanay, 2010). Therefore, considering this benefit mentioned above, a teacher training program that allows the use of current events that will make them blend with the society, stay informed of events happening in the world and Turkey and look at the problems from different perspectives is needed as well as the content knowledge in education given at universities.

It has been concluded that the critical thinking skills of PSTs studying in a teacher-centered traditional teacher training program do not improve. Critical thinking skills of PSTs do not improve, no matter how successful they are in such a teacher training program. For this, it is suggested that the courses and applications that will evoke the meta-cognitive skills are included in the teacher training program and the courses should be revised and adapted to the new understandings in science education. Critical thinking skills of PSTs participating in scientific and cultural activities at university are found to be significantly higher than PSTs who do not participate in them. For this, it is suggested that science activities and out-of-class visits are done more frequently.

\subsection{Suggestions for Critical Thinking Literature}

PST coded as PST-5, who got a low score from the critical thinking test, stated that she was actually a critical thinker, but she was distracted since the test was too long. The length of the scale can be seen as a limitation. It is thought that the fact that some items are related to military events or texts about events in the US constituted a problem for the PSTs who answered the test. In new studies, it is recommended to design critical thinking scales in which there are items related to the culture of the PSTs who will answer the test.

\section{References}

AAS. (1989). Science for all Americans. American association for the advancement of science, Washington, DC.

Ashton, P. (1988). Teaching higher-order thinking and content: An essential ingredient in teacher preparation. Gainesville, FL: University of Florida.

Belluigi, D. Z., \& Cundill, G. (2017). Establishing enabling conditions to develop critical thinking skills: A case of innovative curriculum design in environmental science. Environmental Education Research, 23(7), 950-971. https://doi.org/10.1080/13504622.2015.1072802

Çıkrıkçı, N. (1993). Watson-Glaser eleştirel akıl yürütme gücü ölçeğinin (Form YM) lise öğrencileri üzerindeki ön deneme uygulaması. Ankara Üniversitesi Eğitim Bilimleri Fakültesi Dergisi, 25(2), 559-569. https://doi.org/10.1501/Egifak_0000000599

Clinton, V., Seipel, B., Broek, P., McMaster, K. L., Kendeou, P., Carlson, S. E., \& Rapp, D. N. (2014). Gender differences in inference generation by fourth-grade students. Journal of Research in Reading, 37(4), 356-374. https://doi.org/10.1111/j.1467-9817.2012.01531.x

Creswell, J. W. (2003). Research design: Qualitative, quantitative, and mixed methods approaches (2nd ed.). Thousand Oaks, CA: Sage. 
Creswell, J. W., \& Plano Clark, V. L. (2011). Designing and conducting mixed methods research (s.9). California: Sage.

Demir, M. K. (2006). İlköğretim dördüncü ve beşinci sınıf öğrencilerinin sosyal bilgiler derslerinde eleştirel düşünme düzeylerinin çeşitli değişkenler açısından incelenmesi. Gazi Üniversitesi Gazi Eğitim Fakültesi Dergisi, 26(3), 155-169.

Demiral, Ü. (2014). Fen bilgisi öğretmen adaylarının sosyobilimsel bir konudaki argümantasyon becerilerinin eleştirel düşünme ve bilgi düzeyleri açısından incelenmesi: GDO örneği. Karadeniz Teknik Üniversitesi, Eğitim Bilimleri Enstitüsü, Doktora Tezi.

Demiral, Ü., \& Çepni, S. (2018). Fen bilgisi öğretmen adaylarının sosyobilimsel bir konudaki argümantasyon becerilerinin incelenmesi. Kırşehir Eğitim Fakültesi Dergisi, 19(1), $734-760$. http://dx.doi.org/10.29299/kefad.2018.19.021

Doğanay, A. (2010). Üst düzey düşünme becerilerinin öğretimi. A. Doğanay (Ed.), Öğretim ilke ve yöntemleri içinde (s. 304-352). Ankara: Pegem.

Dunn, D. S., Halonen, J. S., \& Smith, R. A. (Eds.). (2009). Teaching critical thinking in psychology: A handbook of best practices. John Wiley \& Sons.

Ennis, R. (1991). Critical thinking: A streamlined conception. Teaching philosophy, 14(1), 5-24. https://doi.org/10.5840/teachphil19911412

Ernst, J., \& Monroe, M. (2004). The effects of environment-based education on students' critical thinking skills and disposition toward critical thinking. Environmental Education Research, 10(4), 507-522. https://doi.org/10.1080/13504620600942998

Facione, P. A. (1990). Critical thinking: A statement of expert consensus for purposes of educational assessment and instruction. Millbrae, CA: The California Academic Press.

Halpern, D. F. (1998). Teaching critical thinking for transfer across domains: Disposition, skills, structure training, and metacognitive monitoring. American Psychologist, 53(4), 449-455. http://dx.doi.org/10.1037/0003-066X.53.4.449

Jacobson, S. K., McDuff, M. D., \& Monroe, M. C. (2015). Conservation education and outreach techniques. Oxford University Press. https://doi.org/10.1093/acprof:oso/9780198716686.001.0001

Kilinc, A., Demiral, U., \& Kartal, T. (2017). Resistance to dialogic discourse in SSI teaching: The effects of an argumentation-based workshop, teaching practicum, and induction on a preservice science teacher. Journal of Research in Science Teaching, 54(6), 764-789. https://doi.org/10.1002/tea.21385

Kuhn, D. (1999). A developmental model of critical thinking. Educational Researcher, 28(2), 16-46. https://doi.org/10.3102/0013189X028002016

Kuhn, D. (2005). Education for thinking. Cambridge, Massachusetts: Harvard University Press.

Lin, S. S. (2014). Science and non-science undergraduate students' critical thinking and argumentation performance in reading science news report. International Journal of Science and Mathematics Education, 12(5), 1023-1046. http://dx.doi.org/10.1007/s10763-014-9524-2

Lipman, M. (1991). Thinking in education. New York: Cambridge University Press.

Loughran, J. (2014). Professionally developing as a teacher educator. Journal of Teacher Education, 65(4), 271-283. https://doi.org/10.1177/0022487114533386

Miles, M. B., \& Huberman, A. M. (1994). Qualitative data analysis: An expanded sourcebook (2nd ed.). Thousand Oaks, CA: Sage.

Ministry of National Education (MNE). (2018). Science education curricula (Primary School and Secondary School 3, 4, 5, 6, 7 and $8^{\text {th }}$ grade). Retrieved from http://ttkb.meb.gov.tr/

Moore, B. N., \& Parker, R. (1998). Critical thinking (5th ed.). Mountain View, CA: Mayfield.

Morse, J. M. (2003). Principles of mixed methods and multimethod research design. In A. Tashakkori \& C. Teddlie (Eds.), Handbook of mixed methods in social and behavioral research (pp. 189-208). Thousand Oaks, CA: Sage.

National Council for Curriculum and Assessment (NCCA). (2015). Specification for junior cycle science, November, Dublin. 
National Research Council. (1996). National science education standards. National Academies Press, Washington, DC.

Paul, R. (1992). Critical thinking: What every person needs to survive in a rapidly changing world. Tomales, CA: Foundation for Critical Thinking.

Paul, R. W., \& Elder, L. (2008). The miniature guide to critical thinking-concepts and tools (5th ed.). Foundation for Critical Thinking Press, Dillon Beach, CA 94929.

Shukla, D., \& Dungsungnoen, A. P. (2016). Student's perceived level and teachers' teaching strategies of higher order thinking skills: A study on higher educational institutions in Thailand. Journal of Education and Practice, 7(12), 211-219.

Ten Dam, G., \& Volman, M. (2004). Critical thinking as a citizenship competence: Teaching strategies. Learning and Instruction, 14(4), 359-379. https://doi.org/10.1016/j.learninstruc.2004.01.005

Terenzini, P. T., Springer, L., Pascarella, E. T., \& Nora, A. (1995). Academic and out-of-class influences on students' intellectual orientations. The Review of Higher Education, 19(1), 23-44. https://doi.org/10.1353/rhe.1995.0001

URL-1: Türkiye yükseköğretim yeterlilikler çerçevesi, Retrieved from http://tyyc.yok.gov.tr/?pid=48

Watson, G., \& Glaser, E. M. (1980). Watson-Glaser critical thinking appraisal. New York: Psychological Corporation.

Wilks, S. (1995). Critical \& creative thinking: Strategies for classroom inquiry. Heinemann Educational Publishers.

\section{Copyrights}

Copyright for this article is retained by the author, with first publication rights granted to the journal.

This is an open-access article distributed under the terms and conditions of the Creative Commons Attribution license (http://creativecommons.org/licenses/by/4.0/). 